\title{
NOWE ROZDANIE. POLSKIE ARTYSTKI W GALERIE LAMBERT ZOFII I KAZIMIERZA ROMANOWICZÓW
}

\author{
Mirosław A. SUPRUNIUK (Toruń)
}

W Paryżu, w roku 1959, w którym powstała Galerie Lambert, działało ponad sto dwadzieścia różnych galerii sztuki współczesnej, muzeów i miejsc, w których prezentowano dorobek artystyczny. Około dziesięciu z nich to galerie bogate i sławne w Europie, dziesięć następnych zdobyło prestiż w środowisku artystycznym oryginalnością ekspozycji lub konsekwencją w promowaniu nowych talentów, ale większość to galerie anonimowe, wpisane w koloryt miasta. Galerie Lambert, ulokowana na pięknej i starej Wyspie Świętego Ludwika, w samym centrum historycznego cité, była zbyt mała by znaleźć się w pierwszej dziesiątce, ale też zbyt „sławna” w Paryżu, by popaść w anonimowość.

Dziś już każdy paryski krytyk wie, co jest szczególnego w Galerie Lambert — pisano wiosna 1964 roku — od czasu otwarcia — w maju 1959 roku — wystawiało w niej ponad 50 młodych malarzy, w większości z Europy Wschodniej, Azji, Afryki oraz Ameryki Płd. i Hiszpanii. Wśród wystawiających więcej było malarzy abstrakcyjnych niż figuratywnych, ale nie oznacza to jakiejś specjalnej polityki artystycznej czy profilu galerii: głównym jej założeniem jest pokazywanie paryskiej publiczności współczesnych trendów w malarstwie realizowanych poza „,entrami” zachodniej Europy, które mogą się wydawać prowincjonalnymi, chociaż to one stanowią o uniwersalizmie sztuki ${ }^{1}$.

Początki Galerie Lambert są dziś już znane i opisane ${ }^{2}$. Zgromadzone w toruńskim Archiwum Emigracji materiały źródłowe, archiwalia, w tym głównie korespondencje z wystawiającymi w galerii artystami i nabywcami sprzedawanych płócien, są dostępne i badane. W połowie 1958 roku (choć może było to nieco wcześniej) ${ }^{3}$, przylegający do

\footnotetext{
${ }^{1}$ The Galerie Lambert covers five continents, Congress News (Paryż) 1964 (wiosna), s. 1112 - pismo wydawane przez Kongres Wolności Kultury [tłum. - M.A.S.].

${ }^{2}$ Libella Galerie Lambert. Szkice i wspomnienia, red. i oprac. M. A. Supruniuk, Torun 1998.

${ }^{3}$ Jan Lebenstein wspomina, że o projekcie galerii usłyszał już w 1957 roku; por.: [J. Lebenstein], Polski Paryż, rozmowa [M. Smorąg] z Janem Lebensteinem, Ex Libris 1994 nr 44, s. 2-3.
} 
istniejącej już pod numerem 12 Księgarni Libella z jednej, a zlikwidowanej nieco wcześniej wytwórni płyt Ballada-Pavilon Record Comp. z drugiej, niewielki skład starego żelastwa, mieszczący się pod numerem 14 rue Saint-Louis-en-l'Ile został zamknięty, a właścicielka zaproponowała Romanowiczom wynajęcie lokalu po nim 4 . Podobnie wspomina to Zofia Romanowiczowa:

Nasz pomysł zrodził się z przypadku. Obok Libelli, która istniała od 1946 roku, zwolnił się lokal w sąsiedniej kamienicy. Wyspa św. Ludwika była strasznie zaniedbana i nie była wtedy w modzie ani tak snobistyczna jak teraz. Ponieważ byliśmy z wyspą zaprzyjaźnieni [...] właścicielka tej kamienicy zaproponowała, abyśmy go wynajęli. Najpierw to zrobiliśmy, a potem zaczęliśmy się zastanawiać co z tym fantem dalej czynić $[\ldots]^{5}$.

Postanowili założyć galerię obrazów co, biorąc pod uwagę zupełny brak doświadczenia i ryzyko finansowe, było wielką odwagą. Pomysłodawcą galerii był - według Kazimierza Romanowicza - Mieczysław Grydzewski - redaktor naczelny londyńskich „Wiadomości” i wielki przyjaciel Romanowiczów:

nie przypominam sobie, byśmy kiedyś przedtem rozmawiali o malarstwie. A jednak to chyba jemu zawdzięczamy pomysł założenia galerii oraz Irenę Paczkowską, naszą pierwszą uroczą hostessę 6 .

Zdaniem Zofii Romanowiczowej było nieco inaczej:

Pomysł przyszedł nam na jakimś spacerze w okolicach Port Royal w dolinie Chevreuse. Pamiętam ten spacer, pogodę, drogę [...]. Książki - ciężko, ale jakoś idą. Płyty — trudno, Philipsem nigdy nie będziemy [...]. Ale obrazy na tych świeżo malowanych ścianach, żadna sztuka powiesić ${ }^{7}$.

Inicjatywy Grydzewskiego nie sposób jednak wykluczyć, zwłaszcza gdy weźmie się pod uwagę, że zaledwie kilka miesięcy wcześniej, w lutym 1959 roku, otwarta została w Londynie galeria przy aptece Mateusza Grabowskiego — o bardzo podobnym, ,międzynarodowym" charakterze - o której mówiło się w środowisku polskim w Wielkiej Brytanii, a rok wcześniej rozpoczęła działalność Drian Gallery Halimy Nałęcz ${ }^{8}$.

W ocenie współczesnych i przyjaciół Romanowiczów Galerie Lambert weszła na rynek francuski w maju 1959 roku z rozmachem i pewnością siebie, z jaką wchodzili „do jej niewielkiego wnętrza przez eleganckie szklane drzwi, poza dekoracyjnymi, atmosferotwórczymi gapiami, rzesze francuskich i zagranicznych krytyków, dziennikarzy, marszandów, ambasadorów, klientów naprawdę kupujących" — pisała w dwa lata po otwarciu galerii Olga Scherer'. Na wyspie, wówczas taniej i niemodnej, nie

\footnotetext{
${ }^{4}$ A. Kłossowski, Paryska Libella. Czterdzieści lat w stużbie kultury polskiej, [w:] O język $i$ kulturę polska w środowiskach polonijnych, Warszawa 1990, s. 92-93.

5 [Z. Romanowicz], Rozmowa z Zofia Romanowiczowa, rozmowę przeprowadził M. Zaborowski, Obecność $1988 \mathrm{nr}$ 21, s. 39-42.

${ }^{6}$ [K. Romanowicz], Toutes les femmes sont Polonaises, rozmowa [M. Smorąg] z Kazimierzem Romanowiczem, Ex Libris 1994 nr 44, s. 3-4.

${ }^{7}$ Z. Romanowicz, Silva rerum. Galerie Lambert, Wiadomości 1979 nr 28(1737), s. 3.

${ }^{8}$ P. Kądziela, Instytucje polskiego życia kulturalnego w Londynie, [w:] Warszawa nad Tamiza, pod red. A. Friszke, Warszawa 1994, s. 164. Galeria Grabowskiego działała do 1975 roku i wystawiała prócz artystów polskich również plastyków z Anglii i Francji. Najpełniej o Galerii Grabowskiego i Drian Gallery: J. W. Sienkiewicz, Polskie galerie sztuki w Londynie w drugiej potowie XX wieku, Lublin-Londyn 2003.

${ }^{9}$ O. Scherer-Wirska, Śmietanka malarstwa i flaczki po polsku, Tydzień Polski (Londyn) 4.02.1961, s. 5 .
} 
było jeszcze żadnej galerii. Pojawiły się dopiero w początkach lat 60 . i, najpewniej zachęcone sukcesem Romanowiczów, zaczęły powstawać wzdłuż całej, biegnącej środkiem wyspy, ulicy św. Ludwika, zmieniając jej specyficzny XIX-wieczny charakter. Kiedy w maju 1960 roku Les Amis des Beaux-Arts de l'Ile-Saint-Louis, chcąc rozreklamować wyspę, zorganizowali „promenadę artystyczną” przez galerie i ateliers sztuki - począwszy od Galerie Lambert, a skończywszy na Galerie de l'Ile de France przy 33, Quai de Bourbon — galeria Romanowiczów miała już konkurencję.

Galerie połączone z księgarnią nie były czymś wyjątkowym w Paryżu przełomu lat 50. i 60. W ten sposób funkcjonowały np. księgarnia i Galerie Saint-Germain koło Café de Flore, czy goszcząca również polskich artystów w latach późniejszych, Librairie-Galerie Galaxie, przy skrzyżowaniu rue François $\mathrm{I}^{\mathrm{er}}$ i rue Marbeuf oraz kilka innych w dzielnicy łacińskiej. Nie ulega jednak wątpliwości, że dopiero wciągnięcie do współpracy Konstantego A. Jeleńskiego — zwanego przez przyjaciół Kotem — nadało galerii kształtu. Jeleński, związany już wówczas z Leonor Fini, której wystawę zaprezentowało niedawno Muzeum Literatury w Warszawie ${ }^{10}$, stworzył „własną galerię”. Pozostanie tajemnicą, czy bez Kota Romanowicze zdecydowaliby się podjąć ryzyko?

Jeleńskiego poznali, gdy ten przyjechał do Paryża z Włoch na początku lat 50. i nawiązał współpracę z „Kulturą”, którą Libella wydawała. W 1959 roku, gdy powstawała galeria, Jeleński był już w redakcji czasopisma „Preuves” i pracował w sekretariacie Kongresu Wolności Kultury (Congrès pour la Liberté de la Culture), międzynarodowego forum intelektualistów i artystów liberalnych, opozycyjnych wobec dominującego wówczas w kulturze europejskiej marksizmu-leninizmu i spustoszenia, jakie siał on w krajach za żelazną kurtyną, Ameryce Łacińskiej i Azji. W 1955 roku Jeleński wystąpił również (wraz z Danielem Bellem i Ignazio Silone) z inicjatywą stworzenia organizacji wspomagającej intelektualistów z Europy Wschodniej i założył Komitet Pisarzy i Wydawców dla Europejskiej Samopomocy, którego celem była wysyłka książek do krajów za żelazną kurtyną oraz udzielanie stypendiów naukowcom, pisarzom i artystom. Ze zrozumiałych względów starał się, wykorzystując niemałe fundusze obu organizacji, pomagać przede wszystkim Polakom, ale też Węgrom, Czechom, Rosjanom $\mathrm{i}$ innym. Pomoc ta musiała mieć charakter apolityczny, tak, aby korzystający z niej nie byli narażeni na szykany i prześladowania. Współpraca z Libellą, a następnie galerią Romanowiczów pozwalała Jeleńskiemu zarówno na pozory apolityczności, jak i stały kontakt z Polską i Polakami. Znacznie później, gdy komitet przekształcił się w Fundację dla Samopomocy Europejskiej ${ }^{11}$, a Kot, pochłonięty zajęciami w Fundacji Royaumont i w Institut National d'Audiovisuel, miał coraz mniej czasu dla Galerie Lambert, jego rola ograniczyła się do obecności na wernisażach.

Jeleński odegrał wielką rolę w życiu literackim i artystycznym ,polskiego Paryża”. Potrafił patrzeć na obrazy i błyskawicznie oceniać ich wartość — pisali o tym m.in. Józef Czapski, Jan Lebenstein i Olga Scherer ${ }^{12}$ — potrafił też mówić i pisać o malarstwie i przekładać na język słów oglądane płótna. Doradztwo w Galerie Lambert było dla Kota równoznaczne z pisaniem o sztuce. Było odkrywaniem talentów i upartą

${ }^{10}$ Wystawa „Leonor Fini i Konstanty A. Jeleński. Portret podwójny” trwała od 14 października do 30 grudnia 2011 roku.

${ }^{11}$ M. Zaborowski, O Konstantym Jeleńskim..., Obecność 1988 nr 21, s. 37-39; por.: P. Grémion, Konstanty Jeleński a Kongres Wolności Kultury, z franc. tłum. J. Juryś, Kultura $1987 \mathrm{nr}$ 9(480), s. 31-34; M. A. Supruniuk, Przyjaciele wolności. Kongres Wolności Kultury i Polacy, Warszawa 2008, passim.

12 J. Czapski, Hojność btyskawiczna, Zeszyty Literackie 1988 nr 21, s. 6-7; O. Scherer, Wspomnienie, oprac. M. Zaborowski, Obecność 1988 nr 21, s. 42-44. 
obecnością przy dojrzewaniu artysty. Wspomniana wyżej Leonor Fini udostępniła Romanowiczom w pierwszym okresie działalności galerii listę adresów marszandów, kolekcjonerów, snobów, bywalców salonów i krytyków sztuki, co było niezwykle cenne w środowisku zazdrośnie strzegącym własnej pozycji finansowej. Dzięki temu Galerie Lambert już od pierwszych wystaw miała tłumy zwiedzających i kupujących. I były to thumy międzynarodowe ${ }^{13}$. Jeleński był gwarantem jakości organizowanych wystaw, ale też wielką pomocą w sprawach finansowych i organizacyjnych. Nigdy przy tym nie eksponował swego udziału w tworzeniu galerii, pozostając w cieniu, niemal na zewnątrz. Nawet wtedy, gdy w 1973 roku związał się na krótki czas z Galerie Lambert również finansowo ${ }^{14}$. Pisał wtedy do Józefa Czapskiego:

Tak rzadko się widzimy, że nie wiem nawet, czy Ci mówiłem, że wszedłem do spółki z Romanowiczem - to znaczy wnoszę do Galerii (od 1 I 1974) moje „oszczędności” (resztki likwidacji z Kongresu i mieszkania mamy). Nie jestem „współwłaścicielem” Galerii - ale będziemy się dzielić ewentualnym dochodem. Chciałbym w tym roku to ruszyć. Jeśli mi się to uda, bardzo bym chciał zrobić Ci piękną wystawę może z początkiem [19]75 roku? ${ }^{15}$.

Nie ulega wątpliwości, że Kot odegrał decydującą rolę w planowaniu profilu galerii i w doborze wystawiających w niej artystów. Naturalnie, idiosynkrazje i upodobania Romanowiczów miały pewne znaczenie, ale dotyczyły nazwisk, a nie programu i wizji. Zainteresowanie „młodą sztuką” u Jeleńskiego miało bardzo szczególne korzenie i związek ze wspomnianym już wcześniej Kongresem Wolności Kultury. Znaczenie tej instytucji dla promocji polskiej sztuki wymaga osobnych badań i nie jest tematem tego artykułu.

Konstanty Jeleński w połowie lat 50. zainicjował w opiniotwórczym „Preuves” dyskusję na temat „młodej sztuki” w Paryżu. W 1955 roku, po części z jego inicjatywy i pod patronatem „Preuves”, Kongres zorganizował w Rzymie, Brukseli i Paryżu Międzynarodową Wystawę Młodej Sztuki pt. „Pressentir une réalité en acte et en mouvement". Była to pierwsza w Europie wielka prezentacja sztuki artystów dojrzewających w czasie wojny i tuż po niej. Pokazano na niej prace głównie malarzy z Francji, USA, Italii, Wielkiej Brytanii, Belgii, Holandii, Szwajcarii i Polski. Z Polski wystawiali Tadeusz Kulisiewcz i Aleksander Kobzdej. Po wystawach, Jeleński wespół z Alain Jouffroy, rozpisali ankietę wśród młodych malarzy, w której pytali ich o stosunek do tradycji i nowoczesności. Przygotowana ankieta pn. „Tendances de la jeune peinture” zebrała opinie pięćdziesięciu młodych artystów z całego świata, tworzących wówczas w Paryżu, wśród nich Jerzego Kujawskiego. „Sytuacja młodej sztuki w Paryżu” miała z jednej strony ukazać stolicę Francji jako nadal atrakcyjne miejsce dla powstawania nowych tendencji w sztuce, z drugiej, zaznaczyć wejście nowego pokolenia.

Zastanawiające, ale $\mathrm{w}$ korespondencji Jeleńskiego z różnymi osobami, a ukazało się wiele z tych listów w druku, Galerie Lambert i współpraca autora z Romanowiczami, niemal nie istnieje. Można nawet odnieść wrażenie, że dopiero w początkach lat 70 . Kot decyduje się na pełniejsze zaangażowanie w działalność tej instytucji. A wcześniej? Czy była to tylko fachowa pomoc dla Romanowiczów?

\footnotetext{
${ }^{13}$ [Z. Romanowicz], Rozmowa, s. 39-42.

${ }^{14}$ Kot wszedł w rodzaj spółki (także finansowej) z galerią na rok. Potem zostało to rozwiązane; inf. na podstawie listu Zofii Romanowiczowej do autora z 4 lutego 1997.

${ }^{15}$ K. Jeleński, Z listów do Józefa Czapskiego, Zeszyty Literackie $1991 \mathrm{nr} 36$, s. 88 - list bez daty.
} 
Nazwa Galerie Lambert nawiązywała do najważniejszego polskiego symbolu na Wyspie św. Ludwika - Hôtel Lambert. Na wyspie działała księgarnia Libella, nieopodal znajdowała się, założona w 1838 roku, Biblioteka Polska, a w pobliżu wysp działała też, założona w 1833 roku Księgarnia Polska z własnym, bardzo ambitnym wydawnictwem. I był to wówczas prawie cały kulturalny „,polski Paryż”. Instytut Literacki osiadł w odległym o trzydzieści kilometrów podparyskim Maisons-Laffitte, a Centre du Dialogue - miejsce spotkań i dyskusji polityczno-literackich — powstało dopiero w 1973 roku. Wiele lat później powstał też, w miejscu polskiego konsulatu przy rue Jean Goujon, Instytut Polski, lecz choć organizował interesujące i głośne wystawy, odium PRL w dużym stopniu zaciążyło na jego atrakcyjności.

Przełom lat 50. i 60 . był krótkim okresem międzynarodowych sukcesów sztuki polskiej, których najważniejszym akcentem stał się udział grupy malarzy i rzeźbiarzy w pierwszym paryskim Biennale 1959 roku (Pągowska, Szapocznikow, Więckówna, Chrostowska, Gierowski, Tarasin, Dominik, Kierzkowski, Ziemski, Gielniak, Lebenstein). Sukcesy te przemilczano w Polsce, choć w środowiskach artystycznych czuło się, że wolność wypowiadania się w sztuce oznacza konieczność konfrontowania własnych dokonań z doświadczeniami sztuki światowej głównie poprzez wystawy za granicą. W tym bardzo ważnym okresie dla rozwoju polskiej sztuki Galerie Lambert spełniła niemożliwą do przecenienia rolę tratwy ratunkowej.

Pierwsza wystawa w Galerie Lambert miała miejsce w maju 1959 roku. W niewielkim, wyremontowanym i odmalowanym pomieszczeniu zaprezentowano prace malarskie Tadeusza Dominika, młodego malarza abstrakcyjnego z Polski, wyróżnionego rok wcześniej przez Fundację Guggenheima stypendium w Paryżu. Wystawa Dominika, entuzjastycznie przyjęta przez paryską prasę, pozwoliła Galerie Lambert z miejsca osiągnąć pewien prestiż i rozgłos. Sukces Dominika zdystansował wystawiający tuż po nim Japończyk Josaku Maeda, którego wirujące słońca tworzące cykl obrazów Mandala wzbudziły zachwyt. Również następni: surrealista Jugosłowianin Miljenko Stancic oraz Jan Lebenstein z wystawą przygotowaną na pół roku przed triumfem na paryskim Biennale 1959, potwierdzili wysoki poziom i oryginalność propozycji. Dobre recenzje zebrała też wystawa zbiorowa pt. „Sept Jeunes Peintres Polonais” oraz kolejno eksponowane prace: Indianina Souzy (z portugalskiej enklawy Goa), Boliwijczyka Quirogi, Jerzego Zabłockiego z Polski i Węgra Konoka.

O wyborze Galerie Lambert - pisał Konstanty A. Jeleński — nie decyduje styl malarstwa, ale raczej wiek malarza, siła indywidualnego wyrazu [...]. Na małą skalę, bardziej może od innych paryskich galerii, Galerie Lambert świadczy o kurczeniu się świata, a zarazem o sile promieniowania sztuki żywej ${ }^{16}$.

Już pierwsze wernisaże cieszyły się wielkim powodzeniem ${ }^{17}$. W liście do Mieczysława Grydzewskiego z 25 listopada 1959 roku Romanowicz napisał, że w wernisażu Stancica wzięło udział czterysta osób spośród osobistości ze świata artystycznego i dyplomatycznego Paryża oraz wielu Polaków ${ }^{18}$.

Za radą Konstantego A. Jeleńskiego galeria od początku była otwarta dla wszystkich artystów bez względu na kraj pochodzenia czy poglądy na współczesne malar-

\footnotetext{
${ }^{16}$ K. A. Jeleński, Polskie wystawy w Paryżu, Kultura 1960 nr 9(155), s. 122-124.

${ }^{17}$ [K. Romanowicz], Toutes les femmes, s. 5. Wspomina, że kiedyś zajechał pod galerię wóz policyjny z podejrzeniami, że na wyspie szykuje się jakaś demonstracja.

${ }_{18}$ Archiwum Emigracji Biblioteki Uniwersyteckiej w Toruniu (dalej: Archiwum Emigracji), kolekcja: „Wiadomości”, Korespondencja redakcyjna, sygn. AE/AW/CCLXIX, list K. Romanowicza do M. Grydzewskiego z 25 listopada 1959.
} 
stwo $^{19}$. Wystawiali w niej Japończycy, Francuzi, Czesi i Słowacy, Serbowie, Chorwaci, Węgrzy, Rumuni, ale też artyści z USA, Hiszpanii, Niemiec, Anglii, Argentyny, Australii, Korei Południowej, Izraela, a nawet Pakistanu, Mali, Etiopii, Indii, Nigerii, Senegalu, Paragwaju i Sudanu. Oraz, naturalnie, Polacy — głównie malarze i graficy z Polski, chociaż również kilku mieszkających poza Polską. Charakterystyczne jednak, że w porównaniu z polskimi galeriami w Anglii czy Stanach Zjednoczonych, liczba wystawiających u Romanowiczów polskich emigrantów była niewielka.

Wśród wystawiających byli przede wszystkim ludzie młodzi, choć wielu z nich dojrzało i zestarzało się wraz z galerią, prezentując w niej prace regularnie co kilka lat, np. Maeda, Lebenstein, Stancic, Paklikowska-Winnicka, Ladniewska czy Raymond Mirande. Niejeden z artystów stąd właśnie, przedtem nieznany i wszystkim obojętny, wyruszał na podbój Paryża. Nie wszyscy jednak zdobyli sławę, czy odnieśli spektakularny finansowy sukces. Liczył się przede wszystkim przyjazd do Francji, zwłaszcza dla artystów z Europy Środkowej, dla których możliwość wystawiania w Paryżu była równoznaczna z prawem do uprawiania sztuki nowoczesnej.

[...] te niesłychane wrażenia! Iluż niezwykłych ludzi, ile spotkań, które człowieka bogaciły. Byli Czapscy, Kot Jeleński, przyszli oboje Wierzyńscy. Spotkał się ze mną Jean Cassou

— wspominała Teresa Pągowska wystawę z 1961 roku $^{20}$.

O tym, kto wystawiał w Galerie Lambert, decydowali Jeleński z Romanowiczem, biorąc pod uwagę wiek, dorobek i sukcesy artystyczne malarza i radząc się czasem Józefa Czapskiego czy Patricka Waldberga. Jeleński cieszył się pełnym zaufaniem Romanowiczów, zarówno w wyborze artystów, jak i przygotowaniu ekspozycji, selekcji obrazów i rysunków. Brano pod uwagę nie tylko względy artystyczne, ale też, co było nie bez znaczenia, zainteresowania i gusty stałych kolekcjonerów ${ }^{21}$. Do malarza wysyłano list z propozycją wystawy na kilka, a w wypadku artystów z Europy Środkowej nawet kilkanaście, miesięcy przed jej zorganizowaniem. Z czasem artyści sami poczęli zwracać się do galerii z propozycją wystawy, często też korzystali z protekcji przyjaciół, których Galerie Lambert gościła wcześniej. Starzy i stali artyści galerii mieli swoje przywileje. Jan Lebenstein wspominał:

jak tylko coś miałem gotowego — jakieś grafiki, ilustracje do Orwella na przykład wspólnie decydowaliśmy, czy warto to pokazać. Galerie Lambert była akurat salą na tego typu wystawy. Małe, kameralne, drobne formy ${ }^{22}$.

W 1959 roku odbywały się w Paryżu niemal równocześnie, dwie jego wystawy: obrazy olejne prezentowane były w Galerie Lacloche na placu Vendôme (przywilej zwycięzcy Biennale), a gwasze w Galerie Lambert ${ }^{23}$. Możliwość wystawienia obrazów w nowopowstałej, lecz bogatej Galerie Lacloche zawdzięczał Lebenstein Romanowiczowi:

[...] widząc, że dla moich dalszych losów w Paryżu ta wystawa na placu Vendôme była bardzo ważna, zgodził się oddać obrazy Galerie Lacloche, gdzie był większy lokal i lepsze warunki materialne. To był bardzo ładny gest -

${ }^{19}$ [K. Romanowicz], Toutes les femmes, s. 4-5.

${ }^{20}$ Z. Florczak, Galeria Lambert, Przegląd Katolicki 1988 nr 17, s. 3.

${ }^{21}$ [J. Lebenstein], Rozmowa z Janem Lebensteinem o Kocie Jeleńskim, rozmawiał P. Kłoczowski, Zeszyty Literackie 1990 nr 32, s. 110-124.

${ }_{22}^{2}$ [J. Lebenstein], Polski Paryż, s. 3.

${ }^{23}$ Z. Romanowicz, Jan Lebenstein, Wiadomości 1971 nr 3, s. 1. 
wspominał Lebenstein ${ }^{24}$. Sukces Lebensteina spowodował zainteresowanie sztuką polską; w 1960 roku Polacy wystawiali w kilku galeriach poza wyspą św. Ludwika, m.in.: Aleksander Kobzdej w Galerie de la Nouvelle Comédie, Jerzy Tchórzewski w Galerie Furstenberg czy Jan Lewitt (Jan Le Witt) w Galerie Lacloche ${ }^{25}$.

Związki Romanowiczów z intelektualistami ze Wschodniej Europy dostrzegli francuscy krytycy sztuki, widząc w tym przyczyny tak wielkiego zainteresowania malarstwem polskim, jugosłowiańskim czy czeskim. Oryginalność Galerie Lambert została również dostrzeżona w 1964 roku przez organizatorów Paryskiego Biennale Młodego Malarstwa (odbywającego się pod auspicjami André Malraux), którzy włączyli jesienne, dostosowane przez Romanowicza do potrzeb Biennale, ekspozycje galerii do programu wielkich wystaw w paryskim Muzeum Sztuki Nowoczesnej. Podobnie rzecz się miała w latach następnych, aż po znakomitą, szeroko komentowaną w prasie francuskiej, wystawę „La figure humaine” zorganizowaną w ramach Biennale w październiku 1967 roku. Również Kongres Wolności Kultury odkrył wcześnie, że program artystyczny Galerie Lambert koresponduje z jego programem promowania oryginalnych utalentowanych twórców z Afryki, Azji i Ameryki Łacińskiej i wiele wystaw organizowanych w galerii w latach 60. było sponsorowanych przez Kongres.

W Polsce o wystawach Polaków w Galerie Lambert pisał głównie „Przegląd Artystyczny" (począwszy od: $1959 \mathrm{nr} 3$ ), ale drobne informacje o nich pojawiały się od czasu do czasu również w „Przekroju”, „Życiu Literackim” i „Tygodniku Powszechnym”. Ze sporadycznych krajowych artykułów poświęconych galerii warto odnotować dwa: Jerzego Turowicza Polska galeria nad Sekwana z 1964 roku ${ }^{26}$ oraz Aleksandra Wojciechowskiego Galeria Lambert z roku $1965^{27}$.

Wśród stałych gości odwiedzających niemal każdą wystawę bywali: Rena Jeleńska, Olga Scherer, Konstanty A. Jeleński, François Bondy — redaktor naczelny „Preuves”, Piotr Rawicz z przyjaciółmi od Gallimarda, Józef Czapski, Karol Sterling wybitny historyk sztuki, Eric Veaux — w późniejszych latach radca handlowy Francji w Tokio, Tim - karykaturzysta z „L'Express”, Jean Cassou — dyrektor paryskiego Muzeum Sztuki Nowoczesnej — oraz zaprzyjaźnieni z Galerie Lambert pisarze, krytycy i dziennikarze. Trzeba też zaznaczyć, że galeria miała szczęście do krytyków, zarówno autorów wstępów do katalogów, jak i tych piszących o wystawach do prasy polskiej i francuskiej. Najwybitniejszymi z nich byli zawsze życzliwi galerii z ,wyspy skarbów": Patrick Waldberg — jeden z największych znawców surrealizmu ${ }^{28}$, Jean-Marie Dunoyer — redaktor działu artystycznego w „Le Monde”, w którym miał rubrykę „Formes”, Jeanine Warnod (a później Paule Gauthier) z „Le Figaro”, Geneviève Brérette, Michael Gibson z „Herald Tribune” oraz wspomniany wyżej Jean Cassou.

Z niecierpliwością czekało się na comiesięczny wernisaż — mówił Andrzej Wat. — Co miesiąc spotkanie w galerii, potem się szło do takiej kawiarenki na Wyspie Świętego Ludwika. [Au Pont Marie] To była tradycja ${ }^{29}$.

${ }^{24}$ [J. Lebenstein], Polski Paryż, s. 2.

${ }^{25}$ K. A. Jeleński, Polski sezon plastyczny w Paryżu, Kultura 1960 nr 7-8(153-154), s. 192-196.

${ }^{26}$ J. T[urowicz], Polska galeria nad Sekwana, Tygodnik Powszechny 1964 nr 10, s. 3.

27 A. Wojciechowski, Galeria Lambert, Współczesność 1965 nr 17, s. 6. Najpełniejszym opracowaniem na temat wystaw, zawierającym w miarę kompletny wykaz tekstów o galerii do roku 1998 zawiera: Libella Galerie Lambert. Szkice i wspomnienia, s. 227-233.

${ }^{28}$ Był on autorem określenia ,wyspa skarbów” dla Wyspy Świętego Ludwika; zob.: Libella Galerie Lambert. Szkice i wspomnienia, s. 161.

${ }^{29}$ [A. Wat], A mnie jest żal, s. 2. 
Chodziło się też do knajpy przy rue des Boulangers prowadzonej przez tunezyjskiego Żyda, Moryca. Czasem jednak na zapleczu galerii Romanowiczowie organizowali, już po wernisażu, przyjęcie dla malarzy i przyjaciół Galerie Lambert, dla gości z Polski.

Powiedziałbym, że tutaj, na paryskim bruku, wieczory u Romanowiczów odgrywały też inną, specyficzną rolę: były miejscem integracji polskiej inteligencji, tych, którzy tutaj żyli, ale też dochodzących, przyjeżdżających na króciutko z Polski. W galerii bywali zawsze ludzie stamtąd, a więc była ta ciekawość, dowiadywanie się, radość [...] wspominał Andrzej Wat - to był po prostu otwarty dom, miejsce integracji nas tutaj, tego trzonu paryskiego, w sumie skupionego na sobie, łaknącego kontaktu z Krajem [...]. I powiedzmy sobie, kiedy minął ten okres 1957-1958, tego świeżego dopływu z Polski, tej masy nowych ludzi, wernisaże w galerii stały się jego przedłużeniem $[\ldots]^{30}$.

Nie ma, niestety, pełnego spisu wszystkich ekspozycji zorganizowanych w latach 1959-1993 w Galerie Lambert, brak nawet kompletnego wykazu nazwisk artystów, których gościła galeria. Nie znamy również nazwisk artystów, którym Kazimierz Romanowicz i Konstanty Jeleński odmówili wystawy. Ustaleń Aleksandry Olszewskiej i Mirosława Supruniuka z 1998 roku nikt nie zweryfikował ani nie uzupełnił, a szczegółowa analiza obszernego archiwum Galerie Lambert czeka na nowych badaczy ${ }^{31}$. Opierając się na znanych danych, możemy zanotować, że w ciągu niemal trzydziestu pięciu lat działalności Galerii ponad dwustu artystów miało wystawy indywidualne, zorganizowano ponad trzydzieści wystaw zbiorowych, a siedmiokrotnie ekspozycje Galerie Lambert prezentowane były poza Paryżem, również poza Francją ${ }^{32}$. W galerii gościli głównie malarze i malarki (ponad osiemdziesiąt procent) choć nie zawsze prezentowali wyłącznie prace malarskie, poza tym graficy, rzeźbiarze oraz sporadycznie rysownicy i fotograficy. Najczęściej wystawiali Japończycy, niemal równie często Polacy i już dużo rzadziej Francuzi, Czesi i Słowacy, Jugosłowianie, Włosi, Brytyjczycy, malarze z krajów Afryki, Ameryki Łacińskiej, Izraela czy Stanów Zjednoczonych. Wydaje się, że te proporcje czytelne dla pierwszego dwudziestolecia galerii nie uległy zmianie w latach 80., chociaż w ostatnim okresie działalności w Galerie Lambert wystawiało nieco więcej Polaków, co związane było, jak się wydaje, z wydarzeniami politycznymi lat 80 . w Polsce.

Galerie Lambert stała się miejscem konfrontacji młodych malarzy z różnych szkół, ze wszystkich stron świata. Dla większości z nich była to pierwsza okazja pokazania swych prac poza granicami własnego kraju i na dodatek w centrum historycznej stolicy sztuki - w Paryżu. To działało jak magnes, jak zaklęcie. Galerie Lambert była pierwszą po wojnie paryską galerią wystawiającą artystów z krajów Europy Wschodniej: Czechów, Słowaków, Jugosłowian czy Rumunów. Romanowiczom udało się uniknąć emigracyjnego getta, sytuacji gdy obrazy wystawiać będą i kupować wyłącznie Polacy.

Zasługa Romanowicza - wspominał Jan Lebenstein — polegała nie tylko na robieniu wystaw, ale na pomocy w szerokim tego słowa znaczeniu, ci malarze mieli w nim oparcie, nie tylko w sensie finansowym. To było po prostu przyjazne przyjęcie, otwarty dom, wyciągnięta dłoń, człowiek nie zawsze jest zorientowany w układach paryskich, w zwyczajach, w tym co jest przyjęte. Romanowicz był takim życzliwym człowiekiem,

${ }^{30}$ Tamże.

${ }^{31}$ A. Olszewska, M. A. Supruniuk, Wystawy w Galerie Lambert, [w:] Libella Galerie Lambert. Szkice i wspomnienia, s. 107-135.

${ }^{32}$ Romanowiczowie, promując galerię i artystów z nią współpracujących, wysyłali prace z Galerie Lambert do galerii w USA, Kanadzie i Włoszech; zob.: Libella Galerie Lambert. Szkice $i$ wspomnienia, s. 100. 
który objaśniał, radził. Z tego często wychodziły zresztą przyjaźnie. [...] To było jedyne takie polskie miejsce w Paryżu ${ }^{33}$.

Dwudziesta rocznica Galerie Lambert w maju 1979 roku była okazją do podziękowań i wspomnień napływających z całego świata na ręce Romanowiczów. Przytoczmy na koniec jedną z nich, lecz bardzo charakterystyczną:

[...] po pierwszych dwudziestu latach, Wasza Galeria jest nadal uważana przez krytyków, artystów i znawców jako jedna z czołowych, gdzie l'esprit s'enrichit et l'âme se détend. I to wszystko jest dziełem, jedynie i wyłącznie, Was obojga, Waszej współpracy, Waszej inteligencji i intuicji, Waszej gorliwości i przede wszystkim Waszego zaufania i miłości do sztuki, którą w niesłychanie ciepły sposób umiecie okazać nie tylko artystom, ale i tym wszystkim, którzy przekraczają progi Waszej galerii [...]. - Alicja Giangrande ${ }^{34}$.

Już pierwsze wystawy ukształtowały profil Galerie Lambert. I prawie nie było wśród wystawiających kobiet. Pierwszą wystawą z udziałem malarki było „Sept Jeunes Peintres Polonais" (z udziałem prac Ludmiły Murawskiej — jej samej nie wypuszczono z Polski). Odpowiedź na pytanie — dlaczego?, nie jest prosta. W młodej sztuce paryskiej ówczesnych lat kobiet nie było wiele. We wspomnianej wystawie organizowanej przez Kongres w 1955 roku znalazły się zaledwie trzy malarki, te same wzięły udział w ankiecie. Z czasem, w latach 60. i 70. prace artystek coraz częściej pojawiać się będę na ścianach galerii Romanowiczów, jednak tylko sporadycznie będą to prace Polek. Głównie artystek z Polski: Wandy Paklikowskiej-Winnickiej, Wandy Ladniewskiej, Ludmiły Murawskiej, Teresy Mellerowicz, Teresy Pągowskiej, Elżbiety Orel, Teresy Rudowicz, Barbary Gawdzik, Ewy Kuryluk, Teresy Byszewskiej, Haliny Chrostowskiej, Bronisławy (Bronki) Kułakowskiej, Wandy Gołkowskiej, Anny Szpakowskiej-Kujawskiej.

Obok malarek i rzeźbiarek z Polski, wystawiały nieliczne artystki emigrantki: Alicja Giangrande (Argentyna), Stefania Unwin (Belgia), Alexandra Wejchert (Irlandia), czy mieszkające we Francji Arika Madeyska, Alina Ślesińska i Alina Szapocznikow. Jednak tylko dla trzech z nich: Wandy Paklikowskiej-Winnickiej, Wandy Ładniewskiej i Aleksandry Wejchert galeria była miejscem więcej niż dwóch wystaw indywidualnych.

Dla Jeleńskiego, powstająca galeria była okazją do promowania wspomnianej nowej, młodej paryskiej sztuki europejskiej, i — na miarę możliwości — próbą ocalenia Paryża jako centrum sztuki światowej, zwłaszcza, że nikt tego wówczas ,programowo" nie robił. Jeleński znalazł wsparcie w Jeanie Cassou, ówczesnym dyrektorze Muzeum Sztuki Nowoczesnej w Paryżu. I najpewniej w tym należy upatrywać przyczyn, dla których żyjący wówczas jeszcze artyści kręgu Ecole de Paris i inni, ukształtowani w latach międzywojennych, nie mieli możliwości wystawiania w Galerie Lambert. Dotyczyło to również polskich malarek i rzeźbiarek, które tworzyły wówczas i wystawiały w Paryżu, ba, czasem odwiedzały Galerie Lambert: Katarzyna Librowicz, Mela Muter, Stefania Morawska-Ordyńska, Felicja Pacanowska, Zofia Piramowicz, Irena Reno (Hassenberg) i wiele innych.

Powstanie Galerie Lambert, pierwszej i jedynej polskiej galerii sztuki w Paryżu przed końcem lat 80., w znaczący sposób zmieniło obraz sztuki polskich malarzy i malarek w Paryżu. Dla kilku spośród polskich artystów stało się początkiem kariery lub

${ }^{33}$ [J. Lebenstein], Polski Paryż, s. 2-3. Warto przypomnieć, że powstała niemal równocześnie londyńska Galeria Grabowskiego nigdy nie zyskała tego rozgłosu, ani rozmachu co Galerie Lambert i została zamknięta w 1975 roku.

${ }^{34}$ Archiwum Emigracji, archiwum Galerie Lambert, list Alicji Giangrande z Buenos Aires, 30 kwietnia 1979. 
przynajmniej stałej obecności na rynku sztuki. Przyznać jednak trzeba, że wystawy kobiet w ogóle, a artystek polskich w szczególności, stanowiły margines wszystkich wystaw u Romanowiczów ${ }^{35}$. Dotyczy to zarówno liczby, jak i bardzo konkretnego zaangażowania właścicieli galerii w promocję artystek. O ile bowiem, w obu wypadkach, możemy mówić o kilku, może kilkunastu nazwiskach malarzy, których prace pojawiały się bardzo regularnie na wystawach zbiorowych i indywidualnych Galerie Lambert, takich jak wspomniani wyżej: Lebenstein, Maeda (i inni Japończycy), Stancic, Mirande, Dominik, a także: Slobodan Bogojevic, Tadeusz Brzozowski czy Ely Bielutin, o tyle jedynie dwie artystki obecne były na większej liczbie wystaw i, co ważniejsze, jak wynika z korespondencji, mogły korzystać ze wsparcia właścicieli galerii: W. Paklikowska-Winnicka i W. Ładniewska. Inne, o ile nawiązały bliższą współpracę z galerią, mogły liczyć jedynie na wystawy zbiorowe i obecność w ofercie sprzedażnej oraz wystawach accrochage.

W miarę stała obecność w Galerie Lambert obu artystek wydaje się mniej zaskakująca, kiedy dokona się analizy ich biografii artystycznej: Wanda Paklikowska-Winnicka (1911-2001), absolwentka malarstwa warszawskiej ASP, a później, od 1957 roku, docent tej uczelni; w latach 1968-1974 także kierownik Katedry Malarstwa, Rysunku i Projektowania Brył i Płaszczyzn na Wydziale Rzeźby, wystawiała u Romanowiczów niemal od początku. Pierwszą wystawę w Galerie Lambert miała już w czerwcu 1960 roku, zaledwie rok po powstaniu galerii. Była już wówczas zafascynowana malarstwem abstrakcyjnym, malarstwem materii, z silną fakturą, skomplikowaną i dynamiczną kompozycją, przypominającą niekiedy dekoracyjnie tkane materie ${ }^{36}$. Wydaje się, że zarówno malarstwo, jak i zwłaszcza jej „krajowość”, tj. zamieszkanie w Polsce, miało decydujące znaczenie dla K. A. Jeleńskiego, starającego się wprowadzić na rynek francuski nowoczesnych artystów zza żelaznej kurtyny (Polaków, Rosjan, Węgrów, Jugosłowian). Czy Paklikowska-Winnicka korzystała $\mathrm{z}$ innej pomocy instytucji finansujących artystyczną działalność organizacyjną Jeleńskiego, takich jak np. Kongres Wolności Kultury, nie wiemy. Wydaje się, że jej częste pobyty we Francji mogły być finansowane np. przez International Association for Cultural Freedom lub inne tego rodzaju organizacje.

W wypadku drugiej z artystek — Wandy Ładniewskiej-Blankenheimowej (19051995) — ogromne znaczenie dla jej związków z Galerie Lambert, poza artystycznym ouvre, miała również biografia. Urodzona we Lwowie w rodzinie zasymilowanych Żydów, tam ukończyła Uniwersytet Jana Kazimierza i najpewniej szkołę artystyczną, choć nie jest pewne czy rysunek, rzeźbę i historię sztuki — jeszcze we Lwowie, czy już w Paryżu. We Lwowie przyjaźniła się z Tadeuszem Boyem-Żeleńskim. Aresztowana w 1941 roku wraz z mężem Stefanem Blankenheimem, trafiła do niemieckiego obozu koncentracyjnego Auschwitz-Birkenau. Przeżyła; po wyzwoleniu wyjechała z Polski i w 1946 roku zamieszkała we Francji. Wielokrotnie wystawiała w miastach całej Europy: Strasburgu, Frankfurcie, Londynie i Rawennie. Jej prace powojenne, to głównie niewielkie ceramiczne rzeźby, figuracje nawiązujące w tematyce do holocaustu, losu Żydów w czasie wojny. Subtelne, drobne, tkane nerwową linią, ukazywały ofiary holocaustu, bezkształtne figury ludzkie pozbawione cech indywidualnych, jakby wyszarpane i bez dbałości o zbędny szczegół, wyrwane z gliny. Kolejne, skazane na zagładę, zatem bezwartościowe, anonimowe, nieistotne. W dorobku ekspozycyjnym Galerie Lambert twórczość Ładniewskiej

${ }^{35}$ Patrz spis w: A. Olszewska, M. A. Supruniuk, Wystawy w Galerie Lambert, s. 110-135.

${ }^{36}$ M. Sitkowska, Wanda Paklikowska-Winnicka, [w:] Stownik malarzy polskich, t. 2: Od dwudziestolecia międzywojennego do końca XX wieku, [aut. haseł E. Gorządek i in.], Warszawa 2001, s. 264-265. 
była czymś wyjątkowym. Nie sposób ocenić jaki wpływ na bliską i ścisłą współpracę z Galerią Lambert miał fakt, że Zofia Romanowiczowa, współwłaścicielka galerii była również więźniarką niemieckiego obozu koncentracyjnego - Ravensbrück. Dla Romanowiczowej przeżycia wojenne stały się tematem niemal całej twórczości literackiej; dla Ladniewskiej - tematem wypowiedzi artystycznej ${ }^{37}$.

Nie sposób określić znaczenia możliwości ekspozycji swoich dzieł w paryskiej Galerie Lambert dla wystawiających w niej artystek Polek. Dla większości z nich była to przygoda jednorazowa, czasem powtórzona, ale bez znaczenia dla rozwoju artystycznego i kariery artystycznej we Francji, Europie czy kraju zamieszkania. Żadna z artystek polskich, którym Romanowiczowie i Jeleński zorganizowali wystawę na Wyspie Świętego Ludwika w latach 1959-1993 nie osiągnęła spektakularnego sukcesu, ani nie uzyskała statusu „artysty europejskiego” (cokolwiek mogło to znaczyć). Naturalnie, artystki te wystawiały także w innych galeriach paryskich czy francuskich, a często także europejskich i amerykańskich, ale już bez udziału i pomocy Romanowiczów. Jednorazowa obecność Aliny Szapocznikow w Galerie Lambert w 1964 roku, zatem u progu jej emigracji i sukcesów, na zbiorowej wystawie prawie czterdziestu artystów z całego świata, nie miała wpływu na karierę artystki, choć mogła pomóc w pozyskaniu krytyki paryskiej. W tym jednym wypadku wymagałoby to osobnych studiów. Fakt, że później Szapocznikow nie wystawiała w Galerie Lambert potwierdza jedynie tezę, że dla polskich artystek i artystów galeria ta mogła być startem w przyszłość, lecz decydującą rolę odgrywały talent, indywidualność i szczęście.

\section{WYSTAWY W GALERIE LAMBERT Z UDZIALEM POLSKICH ARTYSTEK ${ }^{38}$}

2-28 X 1959

Wystawa zbiorowa pt. „Sept Jeunes Peintres Polonais”.

Przemysław Brykalski, Tadeusz Dominik, Zbigniew Grzybowski, Andrzej Kowalski, Ludmiła Murawska, Teresa Rudowicz, Jerzy Zabłocki.

19 I-4 II 1960

Teresa Mellerowicz (Polska) — malarstwo.

28 V-20 VI 1960

Wanda Paklikowska-Winnicka (Polska) - malarstwo.

24 VI-17 IX 1960

Wystawa zbiorowa pt. „Peintres de la Galerie”, która przypominała prace artystów goszczących w galerii oraz zapoznawała z kilkoma, których wystawy były zamierzone (tzw. accrochage).

M.in.: Wanda Paklikowska-Winnicka, Teresa Pągowska, Alina Ślesińska.

19 V-14 VI 1961

Teresa Pągowska (Polska) — malarstwo.

18 VII-11 IX 1961

Wystawa zbiorowa pt. „Peintres da la Galerie” (tzw. accrochage).

\footnotetext{
${ }^{37}$ Zob.: Archiwum Emigracji, teczka dokumentacyjna W. Ładniewskiej-Blankenheimowej.

${ }^{38}$ Na podstawie: A. Olszewska, M. A. Supruniuk, Wystawy w Galerie Lambert, s. 110-135.
} 
M.in.: Barbara Gawdzik, Teresa Pągowska, Wanda Paklikowska-Winnicka, Alina Ślesińska, Stefania Unwin.

18 V-17 VI 1962

Wystawa zbiorowa pt. „Huit peintres polonais”.

M.in.: Wanda Paklikowska-Winnicka.

14 XII 1962-20 I 1963

Jadwiga Alicja Giangrande (Argentyna) — malarstwo.

22 I-14 II 1963

Halina Chrostowska (Polska) — grafiki.

14 V-8 VI 1963

Elżbieta Orel (Polska) — malarstwo.

10 VII-31 VIII 1963

Wystawa zbiorowa pt. „La boutique d'été”.

M.in.: Wanda Ładniewska, Alicja Giangrande, Elżbieta Orel, Wanda Paklikowska-Winnicka, Halina Chrostowska.

6-29 IX 1963

Arika Madeyska (Polska) — malarstwo.

3 VII-31 VIII 1964

Wystawa „La Boutique d'Été” (tzw. accrochage).

M.in.: Halina Chrostowska, Wanda Ładniewska, Elżbieta Orel, Wanda Paklikowska-Winnicka, Alina Szapocznikow.

5 III-3 IV 1965

Wanda Ładniewska (Polska) — rzeźby.

1-30 IV 1965

Elżbieta Orel (Polska) — malarstwo.

3-31 V 1965

Wanda Paklikowska-Winnicka (Polska) — malarstwo.

5 VII-26 VII 1967

Wystawa zbiorowa pt. „Peintres de Galerie” (tzw. accrochage).

M.in.: Elżbieta Orel, Wanda Paklikowska-Winnicka, Wanda Ładniewska.

8 XI-2 XII 1967

Wystawa zbiorowa pt. „Le Groupe de Wrocław”.

M.in.: Wanda Gołkowska, Anna Szpakowska-Kujawska.

12 I-3 II 1968

Aleksandra Wejchert (Irlandia) — malarstwo. 


\section{5-16 III 1968}

Bronisława (Bronka) Kułakowska (Polska) - malarstwo.

14 II-8 III 1969

Wanda Ladniewska (Polska) — rzeźby.

(?) VII-IX 1969

Wystawa zbiorowa (tzw. accrochage).

M.in.: Alicja Giangrande, Wanda Ładniewska, Wanda Paklikowska-Winnicka.

11 II-? 1972

Wystawa zbiorowa malarstwa i rzeźby.

M.in.: Halina Chrostowska, Barbara Gawdzik, Wanda Ładniewska.

X-XI 1972

Wystawa zbiorowa dwudziestu pięciu artystów.

M.in.: Barbara Gawdzik, Wanda Ładniewska.

6 XII 1972-6 I 1973

Teresa Byszewska (Polska) — grafiki.

9 V-1 VI 1974

Elżbieta Orel (Polska) — malarstwo.

6-30 XI 1974

Ewa Kuryluk (Polska) — malarstwo.

X 1975

Aleksandra Wejchert (Irlandia).

6 IV-28 V 1977

Wystawa „Héritiers et contestataires du romantisme polonais”.

M.in. rzeźby: Wanda Ładniewska.

$10 \mathrm{~V}-? 1984$

Wystawa zbiorowa pt. „Préférences”.

M.in. rzeźby: Wanda Ładniewska.

26 X-26 XI 1988

Aleksandra Wejchert (Irlandia) — relief, grafiki. 
THE NEW DEAL. POLISH ARTISTS IN ZOFIA AND KAZIMIERZ ROMANOWICZS' GALERIE LAMBERT

In the Polish art gallery, operating in the years 1959-1993, on the Île Saint-Louis in Île Saint-Louis in Paris housed exhibitions by artists from all over the world. They were usually young and received their education after World War II. For many it was the main Parisian gallery, among others for the pole Jan Lebenstein, the Japanese Josaku Maeda, or the Yugoslavian Miljenko Stancic. Though female artists displayed their works very rarely there. Merely a dozen or so Polish female artists had their exhibitions in Galerie Lambert. They were young artists, who did not exhibit their works before 1945. None of them achieved an artistic success in Paris, though for Wanda Ładniewska-Blankenheimowa and Wanda Paklikowska-Winnicka the exhibitions have been held often.

KEY WORDS: Galerie Lambert; Polish art in France; Konstanty Jeleński; Kazimierz Romanowicz; Wanda Ladniewska-Blankenheimowa; Wanda Paklikowska-Winnicka. 